approved for 1963-64, as well as re-equipmont of the Dominion Physical Laboratory over the next three years at an estimated cost of $£ 120,000$.

The Council's report also notes the steady improvement in tho educational qualifications of the Department's scientific officers, and the present staff now includes 17 with a D.Se. degree and 99 with a Ph.D. The senior research fellowship programme continues to be most succossful, and an increase in the number of awards from two to five is recommended. Grants to research associations in 1962-63 totalled $£ 169,720$, to universities and agricultural colleges $£ 37,070$, and to the Antarctic Division $£ 126,607$. The highest itoms in the total expenditure of $£ 2,389,000$ are $£ 237,000$ on the Dominion Laboratory and $£ 238,000$ on the Dominion Physical Laboratory. The only other items exceeding $£ 100,000$ are $£ 132,000$ to the Geological Survey, $£ 154,000$ to the Geophysics Division, $£ 114,000$ to the Grasslands Division, $£ 105,000$ to the Plant Diseases Division, and $£ 137,000$ to tho Soil Bureau, but $£ 90,000$ went to the Crop Research Division.

The Secretary's report stresses the value of geochemical prospecting for mineral resources in New Zealand and gives some details of the iron-sand investigations in North Island. Field trials are demonstrating the excellent performance, under farm conditions throughout New Zealand, of the new hybrid ryegrass developed by the Grasslands Division over the past fifteen years. The Plant Chemistry Division has been seeking to find a culture suitable for bacteria of lucerne, clover and trefoil. Two enzyme systems which hydrolyse or decompose sucrose are now being investigated in some New Zealand soils, particularly under introduced pasture. With the present-

\section{TALENT FOR TO-MORROW}

\begin{abstract}
A BOW Group pamphlet, Talent for Tomorrow*, by R. Smith and R. Eddison, arguing that any policy of reform of higher education must be based both on a thorough understanding of the way in which the prosent system works and on some attempt to estimate what will be required of it in the future, discusses the problem in the light of higher education as a determining factor in the character and effectiveness of primary and secondary education. It is in the universitios and colleges that teachers are taught the fundamentals of their profession. Such institutions act not only as a vital factor in our economic potential but also as a means of providing a haven for older men to think as well as for younger mon to learn. Educational policy is not simply a matter for Cabinet discussion and a few crucial decisions at the top: it depends on many decisions at many levels, and, while arguing for closer integration of the political machinery at the centre, the pamphlet also insists on the need for considerable devolution in policy making.

Surveying in the first of the four chapters of the pamphlet the national need, the Bow Group maintains that the major problem in the next twenty years, given continuing economic growth, will be that of educating men and women to a high enough level; and, allowing some 7-10 per cent places for overseas students, as at present, it estimates that in 1980 some 630,000 places will be required in full-time higher education, including 320,000 in universities. These figures compare with 560,000 and 346,000 in the Robbins Report (Nature, 200, 925; 1963), and would provide an annual entry of about 180.000 home students, including 72,000 to universities, and about 16,000 overseas students.

The present pattern of opportunity is considered in the second chapter, which leans very definitely towards
\end{abstract}

day retreat of the Franz Josef Glacier, the opportunity has been taken to examine the microbiology of a series of soils in process of formation from unweathered glacial detritus. Besides investigations on the rate of chemical breakdown, residue and metabolism of demeton methyl, phosphamidon, guthion and dimethoate (Rogor) used to control aphids, a programme of research has been initiated with the view of integrating biological and chemical methods of controlling pests.

An Australian mothod has beon applied succossfully in the ripening of peaches for canning to prevent loss from brown rot, and field trials have established the considerable scope for mechanical soil fumigation in New Zealand. Immediate relief from the chironomid midge in oxidative ponds has been obtained by the judicious use of insecticides, and there seems every prospect of a permanent solution of the problem. Reference is also made to the work of the Botany Division in connexion with the control of noxious weeds and on the incompatibility of plants. A review has been prepared of the features of the Antaretic ionosphere during calm and disturbed conditions, and the effect of $\gamma$-rays and X-rays on certain eugars has been examined with an electron spin resonance spectrometer. Five narrow-angle Geiger tube telescopes have been installed at the Institute of Nuclear Sciences to investigate the daily variations in the intensity of cosmic rays coming from outer space, while industrial research has shown that high-grade rayon pulp can be made from Pinus radiata, which can bo used to manufacture dissolving pulps. A simple and effective instrument has been devoloped for comparing reflexions from opposite surfaces of sheet glass and thus give a measure of its 'waviness' or distorting properties.
10,000 as a reasonable maximum size for a university, and stresses the need for careful preparation before institutions are given the right to confer degrees. It suggests that three of the colleges of advanced technology should be selected for promotion, providing, with the Manchester College of Science and Technology, the Imperial College of Science and Technology, and the now University of Strathelyde, six technological universities which could lead the way in trying out new idoas in technological education. The remaining colleges of advanced technology would keep their present status; but no immediate change in the status of the teacher training colleges is proposed. By 1980 the technological universities would have some 70,000 students, and there would be 170,000 in the regional colleges of technology and commerce and 140,000 in the professional and teacher training colleges. In the 1970's the opportunity to found another 6-10 universities would be welcomed as well as more professional colleges and colleges of technology. Emphasis is laid on the danger of drawing staff from secondary schools in this expansion and on the importance of promoting greater mobility of employment between higher education and other professions, including civil servants and industrial management. Lower staff ratios in the universities seem inevitable but could be offset by employing more administrative, clerical and technical staff, by providing better library facilities and by a more imaginative approach to technical teaching aids, espocially television. The final chapter considers the financial expenditure involved as a national investment, urging that Britain must revise her scale of priorities where education, and especially higher education, is concerned, and be prepared to spend 1.5 per cent of her national income on higher education. At this rate there would be no difficulty in meeting the cost of the expansion plans advocated in the pamphlet. 